\title{
The End of Apartheid: A Redefinition of Nigeria Foreign Policy
}

\author{
Dr. John Danfulani
}

\begin{abstract}
Africa has been the centrepiece of Nigerian foreign policy since the lowering of the Union Jack on $1^{\text {st }}$ October, 1960. This afrocentrists principle has been consistently sustained from the First Republic down to the lane. The nasty experiences with some states in the continent during Nigeria's thirty months of civil war couldn't mastermind a shift in the county's afrocentrist Foreign policy principle. Much of the foreign policy endeavours went to supporting decolonisation processes across the continent and fight against minority racist rule in South Africa. Apart from direct support to liberation movements, Nigeria made a case in international fora in support of colonies under the yoke of colonial domination and racist regimes. That made Nigeria a Frontline State despite being millions of miles away. In 1994 the fight for total liberation of majority blacks of South Africa under Apartheid ended. Consequent to this, Nigeria needs to refashion its foreign policy in tandem with the reality of $21^{\text {st }}$ century international systems. The focus should be how to promote national interest devoid of sentimentalities and fraternities of the 60s, 70s, 80s and early 90s. The country must look beyond continental Africa to climes/bodies that can play a vital role in addressing pressing needs at home. Necessary measures that will send positive signal to outside world of its preparedness via administration of justice, policy consistency and cleansing the system of large scale corruption. Political stability must be on ground to ginger investors to come in without fear of physical and investments insecurity.
\end{abstract}

\section{Introduction}

Apartheid was officially legalised as a state policy in South Africa in 1948 by minority Dutch Boers that mounted the political saddle after the withdrawal of British colonial masters. The basic ethos of Apartheid is racial superiority of minority whites who came into the country in 1652 against indigenous majority black and people of Asian descent known as coloureds. (Marshall, 2006). The majority and other non-Europeans were denied political rights and all civil liberties universally accepted and segregated in public places. This made blacks and the coloureds second class citizens whose existence was at the mercy of the minorities who made their way into the country by forced acquisition of lands and settlements. Ab initio, apartheid was resisted internally and externally. At the home front, many groups notably the African National Congress (ANC), Socialist party and the other Zulu ethnic groups mounted fierce protests against the evil system. As the protests repeatedly fell into deaf ears, the oppressed changed strategy by embarking on acts of sabotage and guerrilla warfare (Mandela, 1994). At some point most of the global community joined in the struggle against Apartheid. This became easy because it coincided with decolonization period and the new states within and outside Africa sympathised with the cause of the majority. However there is no denying the fact that former European colonial masters exhibited lackadaisical attitude to the struggle against apartheid because most still have colonial territories in the Continent (Reddy, 2004).

When pressure by new states skyrocketed to an embarrassing level, they passively caged in by condemning the system without taking stringent measures like total isolation on the white regimes in South Africa. Most of them maintained close ties with the minority regimes thereby shielding it from economic and political pressure coming from Africa and other former colonial territories of South and Latin America and Asia.

At the turn of the last decade of the $20^{\text {th }}$ century, it became clear to practitioners of this inhuman and criminal system that it lacks the muscles and covered goodwill to keep going. The wind of change that collapsed the iron curtains of Eastern Europe and subsequent balkanisation of Union of Soviet Socialist Republic into twelve states signalled to them that it's time to throw in the towel.

Without much ado, President FW de Klerk embarked on reforms aimed at dismantling apartheid via repealing the obnoxious laws that created it. First process was cutting the locks off most of the prisons that held captive the longest political prisoner of Robben Island Mr. Nelson Mandela and a host of his other comrades. The second phase was a protracted negotiation with African National Congress and other liberation struggle groups. After much push and pulls, take and give a political agenda was set. The third phase was conduct of an all-inclusive election that saw to the emergence of the first black president of the rainbow nation in 1994. Nelson Mandela, their leader in power sharing formula that lasted for years (Daily Independent, 2 February 2010). 


\section{Nigeria's Role In Struggle Against Apartheid}

Apart from some frontline states like Zambia, Mozambique, Angola, Zimbabwe and Namibia no other nation took the cross of the struggle against apartheid like Nigeria. Nigeria led the campaign against apartheid at the continental and global levels. Nigeria mobilized sister nations who got self rule in the early sixties and at the OAU level to fight for freedom of blacks in Southern Africa. Through such efforts a special committee was established at the continental body with Nigeria as its permanent chair. The country also mounted fierce campaign at the Commonwealth of Nations clubs and United Nations. Nigeria was again given the position of permanent chair of committee to fight apartheid. (Garba, 1987). Nigeria's foreign affairs minister in Gen. Murtala/Obasanjo's regimes narrated the quantum of fortune the country sank in liberation of South African states. In many instances, the country went solo by picking the bills of programmes associated with the struggle. Thousands of South African youths were given scholarship to study in the country's Universities, nursing schools, polytechnics and colleges of education. On his release from prison, President Nelson Mandela came on a courtesy visit to Nigeria and stated in Kaduna that Nigeria was the first country to make the highest donation to his liberation in the sixties. (Mandela 's Speech on $13^{\text {th }}$ May 1990 in Murtala's Square Kaduna). Even in the 1960s Mandela enunciated Nigeria's dedication to the struggle against Apartheid in a speech delivered at the conference of the Pan-African Freedom Movement of East and Central Africa in 1962. Mandela has this to say "....At the international level, concrete action against South Africa found expression in the expulsion of South Africa from the Commonwealth. These were Ghana, Nigeria and Tangayika (although the latter had not yet achieved its independence).Nigeria also took initiative in moving for the expulsion of South Africa from the international labour organisation....".

The struggle took a more dramatic turn during the regime of Gens. Murtala/Obasanjo from 1975-1979. The struggle was so strong that domestic awareness was mounted to the degree that many tertiary institutions formed clubs like Youth Solidarity on South Africa. Apart from creating domestic and mobilizing public opinion, young Nigerians contributed from their little pocket monies to the struggle. At some level, the then head of State Gen. Olusegun Obasanjo threatened to use all means available to fight down this evil systemincluding invoking blackman's power. It's esoteric if not impossible to know the quantum of Nigeria's financial commitment to the struggle against apartheid because apart from official commitment by government which was in different layers, individuals also committed resources into the struggle in diverse channels.

Nigeria's fight against apartheid was one foreign policy agenda supported by all. It was a less turbulent endeavour than many other foreign policy agendas. The struggle got unreserved blessing of all and sundry, be it military or civilian regimes. The usual north-south, Christians- Muslims dichotomy did not appear in the course of pursuing this foreign policy agenda.

\section{PHILOSOPHY OF NIGERIAN FORIEGN POLICY}

The principle of the Nigeria's foreign policy was enunciated by Prime Minister Abubakar Tafawa Balewa to the parliament shortly before self rule on $1^{\text {st }}$ 0ctober, 1960. Sir Balewa unequivocally stated that Africa shall be the centre piece of the country's foreign policy. Nigeria was portrayed by her pioneer leader as a big brother who will walk through thick and thin to set brothers still shackling under colonial rule and racist regimes free( Balewa's Speech to the Parliament, August 1960). Colonies under imperial domination were assured that they will never walk alone in their march to freedom. This commitment was kept, respected and guarded at all times and in all places. Nigeria spoke where necessary and acted timely and appropriately. It became the county's foreign policy article of faith not only by Sir Balewa's regime that was ousted on $15^{\text {th }}$ January 1966 but all the succeeding regimes. Very little changes were made, where there were, they only bordered strategy and tactic, but the basic tenets were upheld willy nilly (Izah,1991)

This disposition placed Africa as centre of gravity of Nigeria foreign policy. A concise summation of Afrocentrism is Africa and issues affecting the continents will receive rap attention before any other extracontinental matter (Balewa, 1960). This was indeed demonstrated when the idea of forming O.A.U came up and the effort to solving the Congolese crisis that erupted immediately after self rule from Belgium. Nigeria demonstrated that in many other occasions in the early 60 s down to 70 s.

The afro-centrism was advanced by all analysts as the main driving force to the country's unwavering fight that liquidated the evil apartheid in 1994. No doubt no other reason better explained the Nigeria's total commitment that surpasses the commitment of all African countries put together former Nigeria Minister for Foreign Affairs and One time UN permanent representative Gen.Joseph Garba. There is no gainsaying that the front line states suffered cross borders disruptions and invasion of territorial sovereignty by South African defence forces, but that only caused momentary pains because aggressors' continuous territorial transgression were flash actions that never lasted for days. Most of the actions were hot pursue of guerrillas aimed at disruptions of training camps along their common borders.

The gargantuan effort that internationalized the campaign against the system and its financial sustainability rested squarely on Nigeria. This was also possible because Nigeria got self rule as a nation with a 
strong economic base capable of supporting her foreign policy objectives. Another fact was the respect the most populous political geography in continental Africa enjoyed in the continent and the rest of the world at large. That gave the country a credible voice which was heard and respected in the comity of states. Consequent to that, the global community attached utmost seriousness to issues the country tabled in international fora. That undoubtedly made the world to accept the country's proposals to form anti-apartheid committees in O.A.U (African Union) and the UN. That sheer respect and credibility made member states of those bodies to permanently assign chairs of those committees to Nigeria. On countless instances the burden of keeping the spirit alive and footing the bill of those numerous committees was left to the country chairing them. Another clear example is the country's successful mobilization against the evil regime of Apartheid is boycotting of commonwealth games in the 70s. Nigeria went as far as threatening countries and companies dealing with the white's regime (news.bbc.co.uk 17/7/2005).

It is still debateable whether Nigeria started on the right track by making Africa the centre of its foreign policy or not. Some opined it is a noble endeavour in tandem with reality and exigencies of the 60s while others asserted that it was purely a misadventure by a new nation whose leaders were short sighted on driving variables of foreign policies. The later opinions held that the priority at independence should have been nation building through partnership with nations that will help the baby state realise its goal of building a virile black political geography that all blacks can refer to as their natural home like Jewish around the world refer to Zion. This was missed because of excessive meddlesomeness in other climes affairs and carrying of burdens of the burdens of collective agenda that should be concern of all not Nigeria alone (Marafa,2012).

Theoretically, the basic principles can be placed under the idealist ambience of dreaming of a just, peaceful and equitable world. This made the country run foreign policy as an international Non-governmental organization evangelising black fraternity and morality. The afro centralism sapped needed funds to set the new country on right footing and push the new state to greater height.

A realist approach should have been pursuance of policies that will help the nation invest in the future through massive investments in science and technology, modernizing the mainstay of the economy which is agriculture and promotion of domestic unity. Sir Tafawa Balewa's speech in 1960 stated that the country will not align itself as a matter of routine to either the west or east. Later events suggested that the state leaned more to the west than east because of special relationship that was established with the United Kingdom during their 100years of imperial lordship of the country. This made the country lose ample opportunities from the East which were either free or had better conditionality than similar ones coming from the West.

\section{IMPERATIVE OF PARADIGM SHIFT}

Three major events viz the end of ideological war between the West and the East ; complete decolonization of Africa ; collapse of inhuman and racially centred philosophy of apartheid in South Africa challenged the pragmatism of afro centric character of Nigeria foreign policy. All variables that pillared the country's stance have disappeared in the sands of time and those standing are no longer pragmatic.

There is no contesting the realism that national interest which is the guiding compass of all foreign policy endeavours is not considered since 1960. These changes that distorted the former world system should also instigate corresponding changes in the direct principles of the country's policies.

Nigeria is signatory to multilateral and bilateral agreements the continental and sub regional levels. Most of those protocols made the country a beast of burden yoking with responsibilities without direct link with prioritizing its national interest in a transitional world system that many states are struggling to find their bearings.

The country is contributing more than its share in running the African Union head quarter in Addis Ababa, Ethiopian capital. The country is an active participant in all the body's specialised agencies and neck deep into most of the peace keeping operations in near and far climes. Closely related to this is maintaining of full diplomatic missions in most states of the continent. Most of the missions are not for any strategic reasons based on what country is deriving from their host state but more outfit to fulfilling Nigeria's big brother and liberator status. The most absurd of this all is the country do not have more than two dozen citizens in some of these climes doing serious business that is trickling profit home. Worse, there is total lack of strategic interest bordering national security in such states. Nigeria practically do not need more than twelve missions in Africa to realise it goals in the continent. Nigeria's South African mission can successfully manage the country's affairs in the whole of SADEC belt; the Egyptian mission can manage those in the North African states and some parts of Middle East. Nigeria's high commission in Uganda can control East African states. The country can maintain missions with all countries they share common border with namely Cameroon, Niger, Chad and Benin Republic. This is purely for strategic and economic factors. Down the West African sub region, the country can retain its Ghanaian, Ivorian and Senegalese missions because of geographical proximities and shared sub regional strategic and economic interests. 
The country's ECOWAS philosophy is another foreign agenda philosophy that is not paying the country as expected. Apart from the general protocol guiding relationships, the country is into bilateral trade and services providing agreement with most of the states in the region. In the 90s, Nigeria shouldered the financial burdens of peace keeping missions in Liberia and Sierra Leone and provided over 95\% of the manpower. No accurate statistics showing how much the country sunk in those operations because the monies were charged under security votes that are considered classified state secrets hidden from public. These operations went on for years without United Nations Security Council's resolutions recognising them as legal operations. Even after securing the recognition from the global body, there were only dregs of support in terms of finances and logistics from United Nations peace keeping missions.

It is unequivocal that these missions were barren of any convincing strategic or economic interest. Strategically the states of Liberia and Sierra Leone are far off the country, dimming possibilities of any spill over in terms of massive influx of refugee or cross border militia activities. There are countries in between Nigeria and Liberia as well as Sierra Leone and the Atlantic Ocean that ran thousands of kilometres between them. Economically, the military regime did not plan on how to reap the economic benefits from the opportunity by incorporating strategy of businessman taking over mine fields and getting contracts at the reconstruction stage. There was no solid political agenda of a faction to support or leader to hand over their countries to after quelling the crisis. Nigeria kept following the motion pictures scripted and directed by deadly warlords without actually controlling events to promote any national interest.

Before the entry of Ghana into the club of oil producing nations in 2012, Nigeria supplied most of the countries in West African sub region with oil. The terms of payment are not so favourable to the point of not making any economic sense. Despite this, the states involved violate terms of payment entered without fear of attracting punitive measures from their supplier. The country's borders with Benin Republic are routes where all goods slipped into the country without scrupulous monitoring of item within the banned list. This relaxed posture is making the country lose a colossal sum of money in foreign exchange. The policy was anchored on brotherliness not pragmatic national interest. Similarly, Nigeria is supplying Niger Republic with much needed electricity despite chronic shortage at home. The power supplied to Niger is done at an astoundingly subsidised rate. It is real that there is bilateral agreement in the 60s between Nigeria and Niger which dissuaded them from constructing a dam on river Niger which will have an effect on Kainji dam. Decades are down the line without call for review of such protocol in tandem with the realities of Nigeria today. This denied the country an opportunity to review production price per kilowatt and cost of transportation in recognition of current global economic realities.

More to the lack of knitting a strong synergy between national interests in the basic trends of the state's foreign policy, there is consistent conceptual vacillation like: dynamic foreign policy; concert of medium powers; economic diplomacy; citizen diplomacy; and Africa as centre of Nigerian foreign policy. (Pine, 2011). This is another signal of theoretical lameness and lack of direction of the county's foreign policy. Each regime invents a catchy phrase without any philosophical variation with preceding one. The issues or gravitational point remained essentially the same; Africa and Santa Claus disposition to sister states. Most astonishing is how supervising officers delight in reeling out concepts which don't amount to nuisance value in foreign policy and international relations parlances. While Nigeria continued with razzmatazz and busy body foreign policy, other nations with similar power to exert resisted the temptations to waste it on unfruitful extra territorial activism within or outside the continent. Even at early 60s pedestal, Senegal and Cote d' ivore and many new states that emerged from colonial domination were equally stable economically but chose the business of promoting interest in a rancorous and anarchic world of Cold War.

\section{Conclusion}

There is no contesting the realism that Nigeria can't keep this lane in pursuance of foreign policy if at all they want to tackle global factors like world economic recession and growing domestic security snags threatening the foundation of the state. Time is far spent and gargantuan quantum of resources wasted on misadventures that have no direct bearing with bettering the lives of the people. Unequivocal truth that Nigeria must tell the neighbours and those who consider it as big brother that the feast is ended, big brother is tired, stand on your own; no it's no longer easy with me at home and at global level.

The country's energy must be channelled towards attracting foreign direct investments from advanced climes to tackle critical areas of need like electricity, decaying infrastructure, education, health, science and technology. Domestic measures desirable to attracting DFI like cleansing the system of the large scale corruption, political instability; planning and economic policies consistency must be in place.

Nigeria is witnessing unprecedented security challenges that are threatening physical security of citizenry and the pillar of the state. The foreign policy agenda must include partnering with states waging an allout- war on terrorism and request expertise through training of Nigeria's security personnel on how to combat 
the ballooning menace. Incorporating security into the nation's foreign policy is important because without security of lives of locals and foreigners, investors will not come citing insecurity as the stumbling block.

Nigeria has abundant human and natural resources to make one of the success stories of the $21^{\text {st }}$ century. What is needed is purposeful leadership that will take the train of state back on track and keep rolling until life becomes better for the citizens of this nation.

\section{Books}

\section{References}

[1]. Akinyemi, B, "Mohammed/Obasanjo Foreign Policy" in Oyerinde, O. (ed), Nigerian Goverment and Politics under Military rule, 1966-1979, London: Macmillan

[2]. Carey, R. (1992) International Security in the Mordern World, St. Martin's Press

[3]. Claude, I (1964) Power in International Relations. Random House Publishers

[4]. Dougherty, E.J. and Pfaltzgraff Jnr., L. R (1996) Contending Theories of International Relations: a Comprehensive Survey Addisson-Wesley Educational Publishers Inc.

[5]. Gabriel, O. and Akindele, R. (ed) (1990) The Structure and Process of Europe Foreign Making and Implementation in Nigeria. NITA Press

[6]. Garba, J 1987; Diplomatic Soldiering. Spectrum Books ltd

[7]. Holsti, K. J (1972) International Politics: A Framework for Analysis. Prentice Hall Inc.

[8]. Ikimi, T. (1995) Nigeria in the World Community in Ukeaje, I (1990) Nigeria Foreign Policy and Great Power Politics, Lagos. Chinedum Publishers

[9]. Izah, P. P (1991); Continuity and Change in Nigerian Foreign Policy. Ahmadu Bello University Press

[10]. James, A. (1990) Peace keeping in International Relations London Macmillan

[11]. Perkins P (1985); International Relations CBS Publishers and Distributors

[12]. Mandela, N (1994); long Walk to Freedom. London Abacus

[13]. Marshal, H. E (2006); Our Empire Story. Yesterday's Classics

[14]. Olusanya, G.O and Akindele, R. (1986) Nigeria's External Relations: The First Twenty Five Years, Ibadan: University Press Ltd.

Journals

[15]. Nwkeke, A. (1985), "Nigeria's National Interest and Foreign Policy" in Nigerian Journal of International Affairs. Vol. II No. I

[16]. Ogbu, S.O (2001) “Africa as the Centre Piece of Nigeria's Foreign Policy: An Overview” in Journal of Development and Society.

\section{Papers}

[17]. Cecil I Begbu, Peace keeping operations in Africa. Village Square 31/8/2006 -

[18]. Conceptual Confusion: Nikkei Asian Review (Weekly Asian Business Magazine) 4/10/2011

[19]. F.W de Clark, The Day I Ended Apartheid. Daily Independent 2/2/2010

[20]. Lawal M. Marafa, Sustaining Nigeria's Leadership Role in Africa: Business Day 11/4/2012-

\section{Speeches}

[21]. Alhaji Sir Abubakar Tafawa Balewa's acceptance Speech at the UN 8/10/1960

[22]. Enuga S. Reddy: "United Nations and the Campaign against Apartheid" at International Convention Centre, Durban. 10-13/10/2004

[23]. Nelson Mandela "Address at the Conference of the Pan- African Freedom Movement of east and Central Africa” 1996

\section{Websites}

wWw.southafrica.info

www.news.bbc.co.uk/onthisday/africancountriesboycottolympics/ 